Munich Security Brief
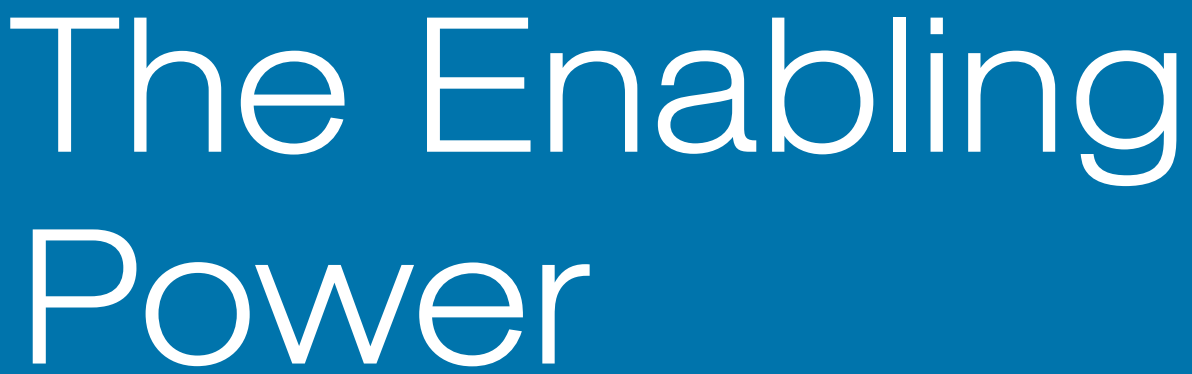

Germany's European Imperative

July 2020 


\section{The Enabling Power Germany's European Imperative}

Tobias Bunde and Sophie Eisentraut

\section{Summary}

The COVID-19 pandemic has created what is probably the single most serious challenge to the survival of the EU as we know it. The sheer magnitude of its economic and political repercussions means that European leaders cannot simply resort to their usual mode of piecemeal and technocratic crisis management. While Germany will not be able to save the European Union on its own, the future of European integration is more dependent on German leadership than ever before. In many parts of Europe, Germany has long been seen as the EU's indispensable power. Germans now need to embrace and implement the "European imperative." Whatever it does in the months ahead, Germany should evaluate its actions according to two criteria: first, whether they enhance the EU's ability to recover economically and politically; and second, whether they enable the EU to become a more credible international actor that is able to protect its values, interests, and sovereignty in an increasingly harsh security environment. 
For about a decade, the EU has been in constant crisis mode. The financial and economic crisis put the architecture of the euro to the test and triggered enduring debates about national fiscal responsibility and European solidarity. The war in Syria demonstrated Europe's inability to put an end to a serious conflict at Europe's doorstep - a conflict that has killed hundreds of thousands of people and strained relations among European nations due to the arrival of increasing numbers of refugees in Europe. The war in Ukraine revealed that the use of military force was still an option on the European continent and exposed the poor state of European defense. ${ }^{1}$ It also highlighted the fact that, without the support of the United States, Europeans would be unable to defend themselves against major military aggression. ${ }^{2}$ The United Kingdom's decision to leave the EU showed that European integration had ceased to be a one-way street towards ever-closer union. In most EU member states, nationalist and populist forces have entered parliaments and shifted the contours of political discourse. In some countries, where they have entered government, illiberal forces have eroded European core values and undermined the rule of law - and the EU has been struggling to respond. While these various crises have different causes, they have often reinforced each other, leading then-President of the European Commission Jean-Claude Juncker to speak of Europe's "polycrisis."

\section{More Than Just Another Element in the "Polycrisis"}

The COVID-19 pandemic is more than just another element in this polycrisis. It has magnified threats to European unity, further deepening internal rifts between EU member states, and has exacerbated global developments that are demanding but also challenging European action in the world. As a result, Europe is now facing a critical juncture. ${ }^{4}$ The choices European actors make in the weeks and months ahead will likely determine the trajectory of the European project: "How the EU of today deals with the crisis will determine the Union of tomorrow. If nationalist answers prevail, nationalism in general will succeed - and the European project will perish." ${ }^{5}$ This is the nightmare that Germany must avoid at all costs.

For this, Berlin needs to change gears. The magnitude of the political and economic repercussions clearly spells the end of Europe's (and Germany's) modus operandi of choice when dealing with crises: largely technocratic, small-scale, and incremental crisis containment rather than durable crisis resolution. The "fragile institutional stalemate" 6 created over the past decade is shaking under the weight of the pandemic. And in light of the hardship caused by COVID-19, "a technocratic, apolitical"7 approach - one that fails to send the strong signal of solidarity - could jeopardize the European project as such.

Fortunately, the COVID-19 pandemic seems to have served as a wake-up call for the German elites by putting a spotlight on the extent of Germany's dependence on Europe. "Germany will only fare well in the long term if Europe fares 
"For Germany, Europe is not something that is merely nice to have or important when other partnerships wilt. No, it is our strongest, our most fundamental national interest." 11

Frank-Walter Steinmeier Munich Security Conference, February 14, 2020 well," ${ }^{8}$ German Chancellor Angela Merkel recently stated. While this is standard German EU rhetoric, against the backdrop of the pandemic it became evident that we are collectively facing a moment of truth: Without a strong Europe - a Europe that is united, prosperous, and capable of taking collective action in the world - German prosperity, German security, and Germany's ability to influence the course of global events will decline.

\section{"Our Strongest, Our Most Fundamental National Interest"}

Recent studies have revealed the extent to which Germany directly benefits from European integration. Germany, they show, has been a major beneficiary of the common currency and the EU's internal market. ${ }^{9}$ It accounts for more than a fifth of intra-EU exports ( $\rightarrow$ see Figure 1). And Germany's ability to freely trade with its European peers raises German incomes by about 1,000 euros per person and year..$^{10}$ Today's Germany is exclusively surrounded by friendly states. Most of them have joined NATO and the European Union, Germany's security and political-economic anchors. Germany has become so used to this privileged position that it sometimes appears to forget that this stability has not been the norm for much of the continent and that not all of its partners feel the same level of security.

Germany's indirect dependence on Europe is no less striking: Without the leverage of the EU - the largest economy in the world, comprising 450 million people - Germany would be unable to defend or in any way shape the open, rules-based international order to which it owes much of its security and wealth. Absent close collaboration with its European partners, Germany would be left at the mercy of the massive challenges that confront it, with climate change, migration, and increasingly fierce competition with illiberal great powers being just the most urgent ones. In an age viewed by elites in Beijing, Moscow, and Washington alike as defined by increased great-power competition, the nation-state offers no refuge - not even for Europe's biggest member state. 
Figure 1: Exports of goods to other EU member states,

2019, percent of total intra-EU exports

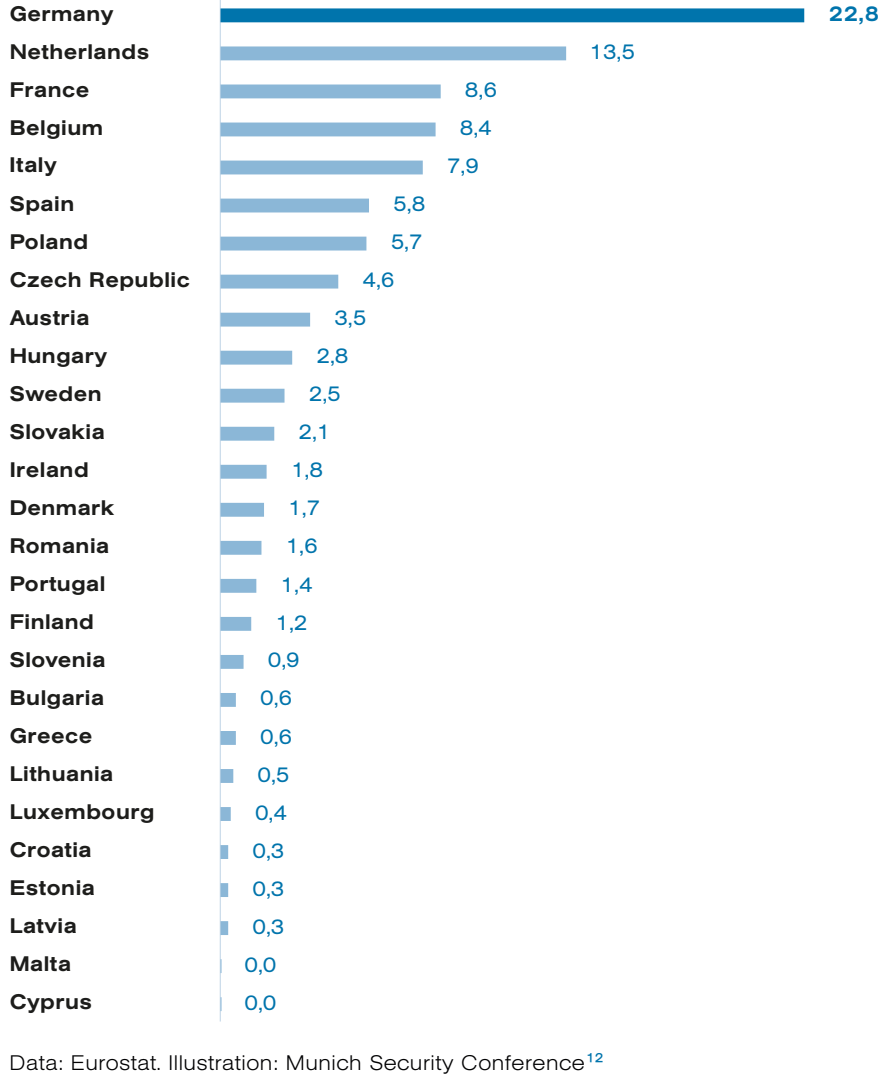

Europe's Future in German Hands?

With Europe standing at the brink, all eyes have turned to Berlin. Whether European economies will recover from the pandemic, whether the EU falls apart or remains united, and whether Europe is able to strengthen its capacity to manage global threats - much of this depends on choices made in Berlin. Yet, German elites and the German public still have to come to terms with the fact that their country has become a pivotal power within the EU. While observers from abroad may sometimes overestimate German power and influence, it is fair to say that Germans generally underestimate how important their country is. They are amazed by (and somewhat scared of) the recent spike in demand for German leadership. And they are bewildered by the fact that massive expectations regarding German leadership are usually matched by equally strong concerns about German domination - and even fears of a return of the "German question." ${ }^{13}$ What some states may perceive as successful German leadership in a moment of crisis, others may view with strong disapproval $(\rightarrow$ see Figure 2). 


\section{Figure 2: Approval of the job performance of Germany's leadership, 2006-2019, percent}

— EU — Visegrad — 'Alliance of Europe's South' _ 'Frugal Four'

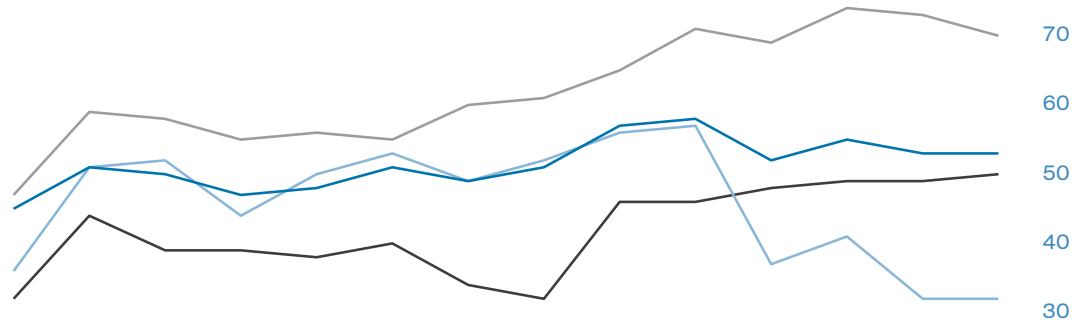

$20062007200820092010 \quad 2011 \quad 2012 \quad 2013 \quad 2014 \quad 2015 \quad 2016 \quad 2017 \quad 20182019$

In a way, the problem Germany now has to deal with - on a much lower level, of course - is the same problem the United States has faced for decades: How much leadership is too much and how much is not enough? But there is no escape from this dilemma. The mode of near-constant crisis management Europe entered almost 10 years ago has significantly increased demands for leadership in the EU. These include demands for decisive action when European treaties lack proper guidelines, calls to build bridges in the wake of growing rifts and fissures within the EU, and requests to provide stability and the public goods most needed in moments of crisis. ${ }^{15}$

Yet, the supply of leadership has been scarce. According to many observers, Germany is a key actor in moments of crisis. Germany has amassed more than a fifth of the EU's GDP and it has the EU's largest population. Moreover, the COVID-19 pandemic is not the first recent crisis that Germany has apparently weathered better than many of its European peers. The financial crisis hit France particularly hard and created an imbalance in the Franco-German engine that has hamstrung the EU ever since. With Brexit, a leading European power is turning its back on the EU.

With power, however, comes responsibility. Yet too often in recent years Berlin has contented itself with telling others what it does not want. The government often appeared more concerned with ignoring or striking down proposals coming from Paris and other capitals than anything else. At the Munich Security Conference 2020, French President Emmanuel Macron, asked whether he was frustrated with the Germans, admitted that he was "impatient" with Germany for its silence on his EU reform proposals. For many in Europe, Germany's real or perceived unwillingness to take up suggestions from others is even more problematic, as Berlin has failed to come up with its own vision for Europe's future. 
"We have a tremendous amount of work to do during your Presidency. My main message is: this is not a moment to think or act small. But a moment for investing in an ambitious Europe. [...] Germany's role and commitment have been a cornerstone of European integration, so we count on Germany to play its full role $[\ldots] . " 16$

Josep Borrell Conference of the Heads of German Missions, May 25, 2020
Throughout Europe, Germany is widely perceived as the EU's indispensable power. ${ }^{17}$ It is time for Germany to act upon it and spur and enable rather than stand in the way of much-needed European initiatives. In short, Berlin must become more proactive, more visionary, and much more European. A Germany that fails to provide enlightened leadership, that prevents or slow-walks bold European plans while occasionally throwing around its weight when it suits its interests, will only deepen the European crisis and will eventually threaten the existence of the EU itself.

\section{The European Imperative}

Henry Kissinger once suggested that political decisions should be guided by two core questions: "What are we trying to achieve?" And "what are we trying to prevent?" ${ }^{18}$ For Germany, the answers to both questions are clear. What we need to prevent at all cost is Europe from falling apart, thus paving the way for the return of nationalism, which has brought war twice in the past century. What we want to achieve is equally clear: We want a Europe that is able to defend its political, economic, and societal model in the world.

This is why Germany must now embrace a "European imperative"19 as the basis for its decision-making. As Foreign Minister Heiko Maas has put it, this requires us to "see European interests as being national interests, and view our national interests through a European lens - and of course [to] act accordingly." ${ }^{20}$ Whatever Berlin intends to do, it should first ask what its actions would mean for Europe's ability to recover from the crisis and for Europe's capacity to protect its values, interests, and self-determination on the world stage.

Unfortunately, in recent years, Germany has not always had the European imperative at heart. Like in other capitals, in Berlin, the first instinct when the pandemic shock arrived in Europe was to engage in national rather than European thinking. ${ }^{21}$ This led to border closures and bans on the export of protective medical equipment. After a few weeks, however, Germany demonstrated its European commitment; it airlifted and treated French and Italian coronavirus patients in German hospitals and donated ventilators and medical equipment to other European countries. ${ }^{22}$ This may be seen as symbolic for the country's general commitment to a "European Germany."

\section{Keeping Europe Together}

The pandemic has upended the plans for the German EU Council Presidency. As German diplomats have noted, the primary task for the next six months will not be business as usual but will be that of "maintaining EU integration as such" ${ }^{23}$ The pandemic could greatly deepen rifts between Europe's hard-hit South and the countries of the North, it threatens to widen fissures between Eastern and Western EU member states over migration and the rule of law, 
and it generally risks strengthening Euroskeptic forces across many member states. And as if this were not enough, emboldened external actors - Russia and China in particular - are eager to exploit the pandemic in efforts "to undermine democratic debate and exacerbate social polarization" 24 in Europe to advance their own agendas. Berlin has to do more to prevent these "big divides" 25 from ripping Europe apart.

In this regard, the asymmetric economic costs imposed by the COVID-19 pandemic and the risk of "entrenched economic, financial, and social divergences" ${ }^{26}$ certainly pose the greatest threats to European unity. In an Italian opinion survey conducted in March and April 2020, 52 percent of the respondents, struggling with the pandemic and disappointed by the perceived lack of assistance from the EU and their European peers, referred to China as a friendly country, while 45 and 38 percent respectively saw Germany and France as "enemy countries." 27 Another opinion poll published in April found that 49 percent of Italians wished to leave the EU. ${ }^{28}$ Observers have rightly argued that while an EU without the United Kingdom is conceivable, an EU without Italy is not. ${ }^{29}$

Germans now have to ask themselves: What do we have to do to keep Europe together? What price must be paid, what risks taken, and what compromises struck to stabilize the European economy and reignite growth in the countries most afflicted by the COVID-19 pandemic? The debates required will not be easy: After all, in Germany, too, European issues are increasingly politicized. At the core of these discussions is the issue of solidarity and the question of whether Europe really is "a community with a common destiny."30 While this question was already pressing in February, when Federal President Frank-Walter Steinmeier raised it at the Munich Security Conference, it is even more urgent now that the aftershocks of the pandemic have fully hit Europe.

In this regard, the recent initiative to create a recovery fund, which Merkel proposed jointly with Macron, is an impressive leap forward - possibly one "of historic importance. ${ }^{31}$ It proves that the grand coalition in Berlin understands what Italy's Prime Minister Giuseppe Conte has elegantly articulated: that EU member states were "writing a page in a history book" rather than "a page in an

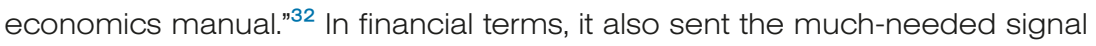
of solidarity and empathy that Berlin had failed to convey in previous crises.

For Germany, the initiative was tantamount to a massive change in mindset. Berlin should use this occasion to once and for all do away with the one-sided narrative of being Europe's paymaster - a narrative long cherished by many policymakers, journalists, and the wider public. After all, it is only natural for leading states to shoulder a greater share of the burden. They also benefit disproportionately. Too often, articles and speeches have discussed EU budget increases without mentioning the benefits of integration, let alone the costs of disintegration. Between 2014 and 2018, the single market increased real incomes in Germany by almost 120 billion euros, while, in the same time 
period, Germany's net contribution to the EU budget varied between 10-15 billion euros per year. ${ }^{33}$ While these calculations often have to be taken with a grain of salt, they still leave no doubt about the overall verdict: The economic benefits Germany accrues alone outweigh the costs it incurs many times over.

Assuming a leadership position also means working on a different domestic framing that the German population can relate to. Rather than focusing discussions on what is "financially undesirable," as German politicians have tended to do, Berlin needs to explain and act upon what is "politically necessary." ${ }^{34}$ When it comes to Europe's economic recovery, this is exactly what the grand coalition did. This type of political leadership needs to extend to other divisive issues on the European agenda, including that of European defense and security. Here, German public opinion may be more supportive than politicians admit. ${ }^{35}$ Interestingly, we are also witnessing a generational change, as a new report demonstrates: It highlights that "the previous majority in favor of 'foreign policy restraint' [...] has substantially decreased," ${ }^{36}$ mostly because younger generations are in favor of increased international engagement.

Yet, making the case for Europe in Germany is not the only task for German leaders. They also have to make the case for Germany in Europe. If Germany is to act as a bridge-builder in a deeply divided EU and forge sustainable compromises on important European issues - from migration and asylum, to climate change and defense - it also has to work on its own credibility. It needs to be perceived as an honest broker in the common European interest, as a legitimate leader that has Europe's best interests at heart. To this end, some critical self-reflection is urgently required.

While Germans have tended to think of themselves as good European citizens and multilateral role models, their European peers see considerable room for improvement. Germany's neighbors point to times when Berlin took unilateral decisions that exhibited little concern for the ripple effects on Germany's European neighbors; they refer to instances in which short-term German interests clearly prevailed over European ones and highlight cases in which they felt Germany did not treat them as an equal partner. Survey data reveal a disconcerting divergence between how Germany perceives itself as a "solidaristic leader" in Europe and its European peers' assessment of it as "a self-interested hegemon." ${ }^{37}$

Indeed, it is not just that Germany's partners perceive it differently. Germany's self-image as a pro-European avant-garde is often contradicted by some simple facts. For example, Germany has consistently been among the countries facing the most infringement proceedings for failing to convert EU directives into national law ( $\rightarrow$ see Figure 3$)$. 
Figure 3: Total number of infringement cases of EU law, 2018

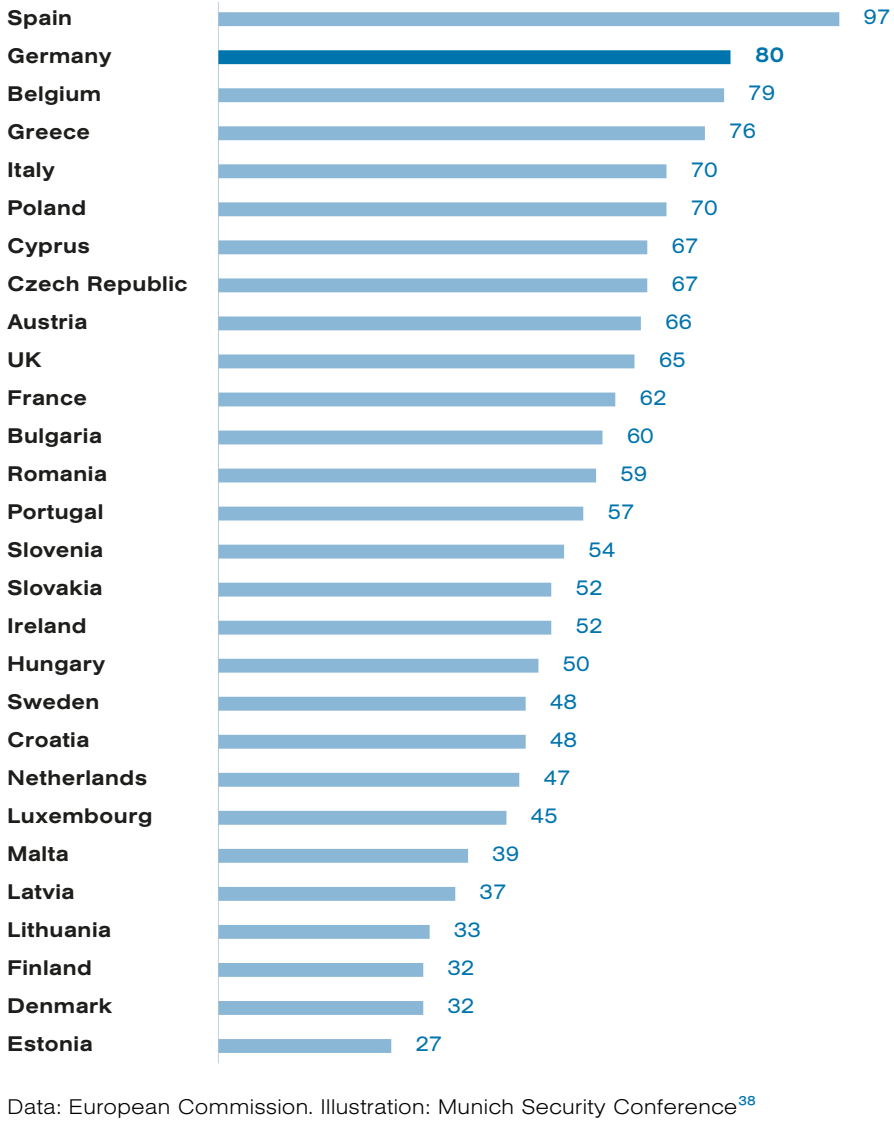

If Germany wants to embrace the European imperative and to do whatever it takes to keep Europe together, it will have to reflect more carefully on the European implications of its domestic decisions, consult more closely with and reassure its European partners, and be more transparent and honest about its own foreign policy goals.

\section{Strengthening Europe's Role in The World: Think Big, Berlin!}

The pandemic does not just pose a massive challenge to European unity. As the defense ministers of France, Germany, Italy, and Spain recently highlighted, "the effects of the pandemic have already started aggravating existing conflicts and crises." ${ }^{39}$ This will raise the stakes for the EU's ability to act in foreign and security policy. To strengthen Europe's ability to defend its values and interests in the world, Germany must take much bolder steps towards fully embracing and implementing the European imperative. 
"[...] Germans and other Europeans need a renewed sense of cohesion and strategic purpose to become more than an appendage to a Eurasia reshaped by China and Russia." 43

Robert Zoellick

Financial Times, October 29, 2019
Most importantly, Germany has to end the "small nation' thinking" 40 of the past. At a time when Europe's ability to "relearn the language of power"41 is called for on various fronts, Germany can no longer pursue policies that mute the EU even further but must seize the opportunity to amplify Europe's voice in the world.

Germany's desire to strengthen Europe's role in the world is still strongly at odds with Berlin's own inability to approach policy issues from a more (geo-) strategic and global angle. This inability was particularly evident in the German debate about the US-EU Transatlantic Trade and Investment Partnership (TTIP). In these discussions, narrow domestic targets took precedence over geopolitical considerations. ${ }^{42}$ In any event, the role TTIP may have played in advancing transatlantic norms and principles in the face of growing competition from illiberal states like China clearly took a backseat. Likewise, the recent debate surrounding US nuclear weapons stationed in Germany gave the impression that this was exclusively a national concern and had few ramifications for NATO or Euro-Atlantic security. Time and again, members of the German political elite have failed to consider the international repercussions of their statements.

Europe, it is increasingly obvious, has to stand its ground in a global environment where economics has become a primary domain for geopolitical competition. Yet, Germany itself has still been reluctant to view its economic relations through a wider geopolitical lens. It continues to rank economic growth and export promotion before non-economic foreign policy goals and pursues these economic goals separately from other priorities. At a moment when Germany's most important trading partners increasingly extend beyond its close strategic allies, this policy is neither sustainable for Germany nor conducive to empowering Europe. ${ }^{44}$ In this regard, Germany's China policy will constitute one of the principal tests of Berlin's willingness to embrace the European imperative.

Germany regularly acknowledges that the most decisive challenges of the future, including climate change, migration, and technological competition, all require European solutions. Still, Berlin often balks at requests to back up its demand for "more Europe" with the necessary resources, financial and otherwise. Embracing the European imperative requires Germany to end this act of "rhetorical acrobatics." ${ }^{45}$ Germany's European climate policies are a primary example. Climate and environmental protection topped the list of priorities for the German EU Council Presidency. However, Berlin has been reluctant to provide the funding needed for the European Commission's ambitious Green Deal.

Climate policies are not the only area where this is the case. Financial nit-picking and concerns about fair burden-sharing often dominate German debates about European policy priorities and how they may best be achieved. ${ }^{46}$ The European imperative demands a public debate that starts from the concrete goals and benefits that Germany seeks to achieve at European level. And it demands that once these goals are defined, Germany invests the resources needed. Recent survey data suggest that Germans do not only desire a more 
active role for their country in Europe ( $\rightarrow$ see Figure 4$)$; they are also willing to provide more money for concrete European policy ambitions, including in the fields of climate protection and innovation. ${ }^{47}$

Figure 4: How German citizens evaluate Germany's role in the EU, 2020, percent

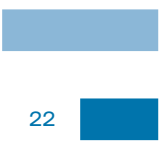

Recently, how active was Germany in the EU?

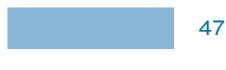

22

In the future, how active should Germany be in the EU? 73

Data: Heinrich Böll Stiftung/Das Progressive Zentrum. Illustration: Munich Security Conference ${ }^{48}$

A Europe able to defend its values and interests in the world is a Europe that speaks with a united, clear, and powerful voice. The starting point includes Germans listening to their neighbors when their core interests are at stake. Germany cannot have a European foreign policy à la carte, i.e., it cannot call for joint European positions on some issues while at the same time - as initially in the case of Nord Stream 2 - trying to restrict European jurisdiction when it sees it as a hindrance. But Berlin should also make it clear that Europe cannot become "weltpolitikfähig"49 if every single government can veto common action for parochial reasons. Put differently: Being guided by the European imperative cannot be understood as acquiescence to a Europe of the lowest common denominator. To this end, Germany should take three steps.

First, as repeatedly suggested by various German leaders, Berlin should continue to make the case for an extension of qualified majority voting (QMV) in the Council to the domain of foreign and security policy and, as a first step, voluntarily waive its veto right. Of course, critics may argue that the risk for Berlin is small, as it is less likely to be outvoted than other countries. But at the very least, it would send a clear signal to the rest of Europe. ${ }^{50}$ Second, Germany should seriously consider how it can make using the veto more costly for others. Abstaining from using its own veto will certainly help, but it is clearly not enough. And third, Germany needs to be more willing to forge ahead with a critical mass of like-minded partners when the EU's consensus requirement gets in the way of action. In the area of the Common Foreign and Security Policy, this exigency is particularly urgent. Here and elsewhere, Berlin must not hide behind a lack of consensus but should actively seek partners that share an ambitious agenda for Europe. Of course, this means reinvigorating the Franco-German partnership, which has recently shown the way in the economic realm but should also be more active in foreign and security policy. A Germany that has the European imperative at heart should not press ahead without properly consulting or reassuring its neighbors. But it should 
"I think that Europe and especially my country have a duty to become more able and more willing to act. Because we Germans and Europeans are faced with a strategic situation that is increasingly dominated by great power competition." 55

Annegret Kramp-Karrenbauer Munich Security Conference, February 15, 2020 also not allow individual European countries to paralyze the European project and prevent efforts to update it so that it can cope with the challenges of a changing global environment.

Naturally, the partnerships Berlin needs to foster in order to defend European values and interests in the world extend well beyond the EU. Most importantly, following Brexit, it will fall to Berlin to ensure that relations between the United States and the EU remain as strong as possible. And Germany should also work with France to secure close coordination and cooperation with the United Kingdom.

Germany should also send a signal to the world, stressing the German ambition to turn the EU into a credible foreign policy actor. There is no need to spend too much time on semantic debates about the true meanings of "strategic autonomy" or "European sovereignty." But there is a clear need to enhance Europe's ability to act. Europe's lack of influence on the course of conflicts that have affected its core interests - most notably those in Syria and Libya - has been all too evident. While Europeans have been quick to criticize the United States for abandoning its traditional role, the European approach has been "even more impotent and inward-looking than that of the United States." ${ }^{51}$ A world of "Westlessness" 52 is also a consequence of Europe's apparent inability to defend its core interests. While Commission President Ursula von der Leyen has promised a "geopolitical Commission," ${ }^{53}$ Josep Borrell has repeatedly underlined the necessity for Europe to "relearn the language of power." ${ }^{54}$ European leaders must make sure that these grandiose claims are filled with meaning.

In any case, it is obvious that the EU will not learn to speak the language of power as long as Germany does not. Even in a world increasingly shaped by great-power competition, it still makes sense to defend the European model of multilateral cooperation, trying to forge win-win situations or investing in rules-based frameworks. But this should be done from a clear-eyed position of strength and based on reciprocity, in cognizance of the fact that other actors do not share the European worldview. Even the United States has to adapt to a new era of great-power competition, in which the US is facing increasingly powerful rivals in a world where liberal democracy is no longer the "only game in town." For the EU, which was essentially designed to overcome a "dog-eatdog" world, the learning curve is far steeper. It is still new to the great-power game ${ }^{56}$ For very good reasons, Europeans, and Germans in particular, detest the kinds of policies that come with it. Yet, even if they operate differently, Europeans must learn how to respond more decisively and effectively to attacks on their core values and interests. What kind of message does it send if repeated attempts to attack parliaments or to undermine the integrity of elections - the critical infrastructure of European democracies - are not met with a strong response? With Berlin's help, Europe must make sure everyone understands it will not accept being bullied and will mobilize its special set of resources to push back. 


\section{Germany Has Become Europe's Indispensable Power: Let's Face It - Let's Embrace It!}

This plea for Germany to embrace the European imperative and accept the leadership role that is part of it should not be misunderstood. German cannot - and will not - lead on its own. It must always build coalitions, with France remaining its first and foremost partner. What is needed is a "European Germany," as Thomas Mann put it. It is a Germany that is aware of its limits. But it is also one that is aware of its influence. "Italy's future is in German hands" was the title of a recent article. ${ }^{57}$ But German leaders and the German public often seem blissfully unaware of the fact that decisions made and actions taken in Berlin are sometimes matters of life and death for its partners.

German leadership based on the European imperative would acknowledge and anticipate the ripple effects of German decisions and actions for Europe. More important still, it would create a simple but powerful benchmark for all political decisions taken in Berlin: First and foremost, they must be geared towards strengthening Europe. If Berlin throws its full weight behind the EU it can become Europe's "enabling power." A Germany that succeeds in this aim would finally have embraced the type of leadership that its partners have rightly demanded of it - a modern, visionary, enlightened form of leadership in Europe. 


\section{Notes}

1 David Bachmann et al., "More European, More Connected and More Capable. Building the European Armed Forces of the Future," Munich/Berlin: Munich Security Conference, McKinsey \& Company and Hertie School of Governance, November 2017, https://perma.cc/KAG2-DVPC.

2 Ben Barry et al., "Defending Europe: Scenario-based Capability Requirements for NATO's European Members," London: The International Institute for Strategic Studies (IISS), May 10, 2019, https://perma.cc/GG9Y-ZZK5.

3 Jean-Claude Juncker, "Speech by President Jean-Claude Juncker at the Opening Plenary Session of the Ideas Lab 2018 'Europe - Back on Track' of the Centre for European Policy Studies," Brussels, February 22, 2018, https://perma.cc/J7JT-DH7U.

4 Wolfgang Ischinger and Boris Ruge, "Für Europa ist es eine Überlebensfrage," Zeit Online, April 2, 2020, https://perma.cc/N3SW-FYQG. An English translation is available at $h$ ttps://perma.cc/Q33C-QDG8.

5 Tobias Bunde et al., "European Vision and Ambition Needed: Italy and Germany Must Promote a Global Response to COVID-19" (IAI Commentary 20/27), Rome: Istituto Affari Internazionali, https://perma.cc/9WH2-GQ6T.

6 Heather Conley, "An Eroding European Union," Washington, DC: Center for Strategic and International Studies, April 6, 2020, https://perma.cc/CE46-B95K.

7 Henrik Enderlein, "We All Die Alone," Berlin: Hertie School - Jacques Delors Centre, April 13, 2020, https://perma.cc/7WSU-V6ZH.

8 Angela Merkel, "Speech by Federal Chancellor Angela Merkel at the Konrad-Adenauer-Stiftung Event on Foreign and Security Policy During Germany's EU Council Presidency," Berlin, May 27, 2020, https://perma.cc/FA4Y-AUCF.

9 Giordano Mion and Dominic Ponattu, "Estimating Economic Benefits of the Single Market for European Countries and Regions," Gütersloh: Bertelsmann Stiftung, May 2019, https://perma.cc/U7B2-LXPY; Alessandro Gasparotti and Matthias Kullas, "20 Years of the Euro: Winners and Losers," Freiburg: Centrum für Europäische Politik, February 2019, https://perma.cc/9G9F-QHA5.

10 Mion and Ponattu, "Estimating Economic Benefits."

11 Frank-Walter Steinmeier, "Opening of the Munich Security Conference," February 14, 2020, https://perma.cc/R7EW-DR55

12 Illustration by the Munich Security Conference based on Eurostat, "Intra-EU Trade in Goods - Main Features," April 2020, https://perma.cc/5PGH-ANRS.

13 Robert Kagan, "The New German Question. What Happens When Europe Comes Apart?," Foreign Affairs 98, no. 3 (May/June 2019), https://perma.cc/3RBH-KNQP Hans Kundnani, "We Need to Talk About Germany," Foreign Affairs 98, no. 5 (September/October 2019), https://perma.cc/78PH-3TBM.
14 Illustration by the Munich Security Conference based on data provided by Gallup World Poll. The EU includes all 28 member states with the exception of Germany; the Visegrad group includes the Czech Republic, Hungary, Poland, and Slovakia; the 'Alliance of Europe's South' includes Cyprus, France, Greece, Italy, Malta, Portugal, and Spain; and the 'Frugal Four' include Austria, Denmark, Sweden and the Netherlands.

15 Simon Bulmer, "Deutschland in der EU: Europas unverzichtbarer Hegemon?," integration 49, no. 1 (April 2019), https://perma.cc/Z8LF-CGUP.

16 Josep Borrell, "Opening Speech by Josep Borrell, High Representative of the Union for Foreign Affairs and Security Policy, on the Occasion of the 18th Conference of the Heads of German Missions," 25 May 2020, https://perma.cc/P9NW-RBLK.

17 Radoslaw Sikorski, “I Fear Germany's Power Less Than Her Inactivity," Financial Times, November 28, 2011, https://perma.cc/4XNW-K5MV.

18 Henry Kissinger, "Kissinger: Great Things Cannot Be Achieved Without Some Sacrifice of the Present for the Needs of the Future," Atlantic Council, October 3, 2015, https://perma.cc/C4W8-WAR7.

19 Foreign Minister Heiko Maas used the term in his address to the German ambassadors. See Heiko Maas, "Speech by Federal Minister Heiko Maas at the opening of the 18th Conference of the Heads of German Missions," Berlin, May 25, 2020, https://perma.cc/7V59-G35K.

20 Maas, "Eröffnung der 18. Konferenz."

21 Enderlein, "We All Die Alone"; Wolfgang Ischinger and Boris Ruge, "Für Europa ist es eine Überlebensfrage."

22 Elisabeth Braw, "Forget Washington and Beijing. These Days Global Leadership Comes From Berlin," Foreign Policy, April 28, 2020, https://perma.cc/26RZ-BKEL.

23 Cornelius Adebahr, "Beyond European Crisis Management - Germany Needs a Post-Coronavirus Vision," Ludwigsfelde: Stiftung Genshagen, May 25, 2020, https://perma.cc/UBT5-EMD4.

24 European Commission and High Representative of the Union for Foreign Affairs and Security Policy, "Tackling COVID-19 Disinformation - Getting the Facts Right, Joint Communication to the European Parliament, the European Council, the Council, the European Economic and Social Committee and the Committee of the Regions," Brussels, June 10, 2020, https://perma.cc/6A64-4CS3, p. 3

25 Josep Borrell, “Annual German Ambassadors' Conference 2020: Opening Remarks by High Representative/Vice President Josep Borrell," May 25, 2020, https://perma.cc/994B-YXA5.

26 European Commission, "Spring 2020 Economic Forecast: A Deep and Uneven Recession, an Uncertain Recovery," May 6, 2020, https://perma.cc/YU5Y-JVBY. 
27 Francesco Bechis, "Se gli italiani preferiscono la Cina agli Usa (e alla Ue)," Formiche, April 21, 2020 , https://perma.cc/B2VM-KTFM

28 Redazione DiRE, "Sondaggio Dire-Tecnè: aumentano gli italiani che vorrebbero uscire dall'Ue," DiRE, April 4, 2020, https://perma.cc/FPC8-S6HN.

29 Timothy Garton Ash, "Die Krise kann Europa stärken - wenn Deutschland das Nötige tut," Der Tagesspiegel, April 7, 2020, https://perma.cc/5DLP-V6UJ.

30 Steinmeier, "Opening of the Munich Security Conference."

31 Anna Diamantopoulou, "Five Ways That the Coronavirus Should Transform the EU," European Council on Foreign Relations, June 3, 2020, https://perma.cc/TC6M-Q5VK.

32 Silvia Amaro, "Italy Readies More Economic Stimulus as Its Coronavirus Death Toll Surpasses 12,000," CNBC, April 1 2020, https://perma.cc/VE9J-TEWL.

33 Representation of the European Commission in Germany, "Oettinger zu EU-Finanzen nach 2020: Nettozahler-Debatte ist zunehmend sinnentleert," February 14, 2018, https://perma.cc/E3CQ-SRUL; Representation of the European Commission in Germany, "Mythos: Wir Deutsche zahlen für den Rest Europas,“ May 9, 2019, https://perma.cc/ZG6Y-ZBRN.

34 Johannes Hillje and Christine Pütz, "Selbstverständlich europäisch!? 2020. Der Auftrag für die EURatspräsidentschaft," Heinrich-Böll-Stiftung/Das Progressive Zentrum, March 2020, https://perma.cc/9ZA4-M6AM.

35 In the fall, the Munich Security Conference will publish a special edition of the Munich Security Report on German foreign and security policy, which will also discuss the developments of German public opinion in more detail.

36 Philipp Rotmann, Sarah Bressan and Sarah Brockmeier, "New Expectations: Generation Z and Changing Attitudes on German Foreign Policy," Berlin: Global Public Policy Institute, May 2020, https://perma.cc/QD3N-MVYL, p. 2.

37 Alessandro Pellegata, "Mass Vs Elites \#7: Elites Evaluate Germany's Role During the Crisis," EuVisions, March 5, 2019, https://perma.cc/3SZH-8GVZ.

38 Illustration by the Munich Security Conference based on European Commission, "Monitoring the Application of European Union Law. Annual Report 2018," July 2019, https://perma.cc/33ER-CHGJ.

39 Letter to Josep Borrell and to their European colleagues sent by Florence Parly, Annegret Kramp-Karrenbauer, Margarita Robles Fernández, and Lorenzo Guerini, May 2020, available at $h t t p s: / / p e r m a . c c / 7 W M L-2 H 2 B$.

40 Sophia Besch and Christian Odendahl, "The Good European? Why Germany's Policy Ambitions Must Match Its Power," Centre For European Reform, February 2020, https://perma.cc/7HZW-7C59.

41 Josep Borrell, “Embracing Europe's Power," Project Syndicate, February 8, 2020, https://perma.cc/C35M-H99G.
42 Besch and Odendahl, "The Good European."

43 Robert Zoellick, "German Reunification Gave Europe Strategic Purpose," Financial Times, 29 October 2019 , https://perma.cc/7LU9-L67D.

44 Thomas Kleine-Brockhoff and Hanns W. Maull, "Der überforderte Hegemon. Ziele und Grenzen deutscher Macht,“ Internationale Politik 66, no. 6 (November/ December 2011), https://perma.cc/3PA8-EFTN.

45 Andreas Kluth, "Why Germany Will Never Be Europe's Leader," Bloomberg Opinion, April 30, 2020, https://perma.cc/W57X-3GZF.

46 Hillje and Pütz, "Selbstverständlich europäisch."

47 Hillje and Pütz, "Selbstverständlich europäisch."

48 Illustration by the Munich Security Conference based on Hillje and Pütz, "Selbstverständlich europäisch." The data is based on an online survey conducted in January 2020.

49 Jean-Claude Juncker, "Rede von Präsident Jean-Claude Juncker anlässlich der 54. Münchner Sicherheitskonferenz,“ February 17, 2018, https://perma.cc/WM2R-C979.

50 For an overview of national preferences regarding QMV and alternative paths towards more efficient and effective EU external action" see Nicole Koenig, "Qualified Majority Voting in EU Foreign Policy: Mapping Preferences," Berlin: Hertie School - Jacques Delors Centre, February 10, 2020, https://perma.cc/9VA4-7DKY.

51 Gideon Rachman, "End of the American Era in the Middle East," Financial Times, December 30, 2019, https://perma.cc/JRT8-RJ63.

52 Tobias Bunde et al., "Munich Security Report 2020: Westlessness," Munich: Munich Security Conference, https://perma.cc/7NHA-ZLV9.

53 European Commission, "The von der Leyen Commission: For a Union That Strives For More," Brussels, September 10, 2019, https://perma.cc/59DV-Z4XK.

54 Borrell, "Embracing Europe's Power."

55 Annegret Kramp-Karrenbauer, "Defending the West Speech by Federal Minister of Defence Annegret Kramp-Karrenbauer at the Munich Security Conference," Munich, February 15, 2020, https://perma.cc/ZWS7-3CTM.

56 Zaki Laïdi, "Can Europe Learn To Play Power Politics?," London: Centre for European Reform, https://perma.cc/Y6UD-UL5U.

57 Silvia Sciorilli Borrelli and Matthew Karnitschnig, "Italy's Future Is in German Hands," Politico, April 2, 2020, https://perma.cc/7FAP-N5AG. 


\section{The Authors}

Dr. Tobias Bunde is Head of Policy \& Analysis at the Munich Security Conference and a postdoctoral researcher at the Hertie School's Centre for International Security.

Dr. Sophie Eisentraut is a Senior Policy Advisor at the Munich Security Conference.

The authors would like to thank Laura Hartmann, Franziska Stärk, and Ulrike Strauß for their indispensable support in completing this Munich Security Brief.

\section{The Munich Security Conference (MSC)}

The Munich Security Conference is the world's leading forum for debating international security policy. In addition to its annual flagship conference, the MSC regularly convenes high-profile events around the world. The MSC also publishes the annual Munich Security Report and other formats on specific security issues.

\section{The Munich Security Briefs}

With its Munich Security Briefs, the MSC aims at contributing to ongoing debates on particular issues within the broad field of international security. A much more concise format than the Munich Security Report, the briefs are meant to provide both an overview of an issue as well as a succinct analysis of its policy implications and strategic consequences. They generally express the opinion of their author(s) rather than any position of the Munich Security Conference. 


\section{Imprint}

Editorial Board:

Ambassador Wolfgang Ischinger, Ambassador Boris Ruge,

Dr. Benedikt Franke

Production:

Laura Hartmann, Franziska Stärk, Ulrike Strauß

Design:

MetaDesign

Copy-editing:

Roisin Cronin

Stiftung Münchner Sicherheitskonferenz gGmbH

Karolinenplatz 3

80333 München

www.securityconference.org

research@securityconference.org

Visit our website, app, and social media channels: www.linktr.ee/MunSecConf

Should you wish to reproduce parts of this Munich Security Brief, please ensure that you acknowledge the original source and consult with the contributing organization or institution.

Please cite as: Tobias Bunde/Sophie Eisentraut: The Enabling Power. Germany's European Imperative (Munich Security Brief, July 2020), Munich: Munich Security Conference.

A German version of this Munich Security Brief, titled "Die Möglich-Macher-Macht. Deutschlands europäischer Imperativ," is available on our website as well. 